\title{
Középiskolai koffeinfogyasztási szokások
}

\section{Caffeinated beverages consumption habits among high school students}
Szerzők: $\quad$ Bornemisza Ágnes ${ }^{a} \bowtie$, Csővári Melinda $^{b}$, Varga Bernadett ${ }^{a}$
a: Pécsi Tudományegyetem, Egészségtudományi Kar, Kaposvári Képzési Központ, Kaposvár, b: védőnő, Kiskőrös

Beküldve: 2020.02.14.

doi: $\quad$ 10.24365/ef.v61i4.564

\begin{abstract}
Összefoglaló:
Háttér: Az utóbbi évtizedben a fiatalok körében egyre jobban elterjedőben van a magas koffeintartalmú italok fogyasztása. A középiskolás korosztály gyakran nincs tudatában kockázatkereső magatartásának veszélyeivel, ezt állíthatjuk a koffeintartalmú italok fogyasztása terén is. Jelen kutatás céljaként felmérésre kerültek a különböző iskolatípusba járó diákok közötti eltérő koffein- és energiaitalfogyasztási szokások.
\end{abstract}

Módszertan: A kutatás módszere saját szerkesztésű, önkitöltős kérdőív, melyben szociodemográfiai adatok, koffeintartalmú italok fogyasztására vonatkozó adatok, e termékekkel kapcsolatos vásárlási szokások és életmódot érintő kérdések voltak. Az adatok feldolgozása leíró statisztikai elemzés mellett Khi-négyzet próba segítségével történt.

Eredmények: A megkérdezett 180 diák átlagéletkora 18,2 év, a lányok aránya 61\% volt. A válaszoló szakközépiskolában tanuló diákok nagyobb arányban és gyakrabban fogyasztottak energiaitalt, és szívesebben próbálták ki az újonnan megjelenő, különböző márkájú energiaitalokat, mint a gimnáziumi tanulók. A kisebb településen élő válaszadókra jellemző volt a túlzott energiaital-bevitel, és kevésbé tartották fontosnak a koffeines termék élénkítő hatását, ehelyett náluk inkább az íz dominált. A válaszoló városi diákok nagyobb arányban tartották kedvenc italnak a kávét, mint a faluból, községből jött társaik. A lányok között sokkal közkedveltebb ital volt a kávé, mint a fiúknál. A kérdőívet kitöltött lányokra jellemzőbb volt, hogy állításuk szerint gyorsabban elfáradnak, ha nem isznak koffeines terméket.

Következtetések: Szükséges lenne már gyermekkorban elkezdeni az egészséges életmódra nevelést, hiszen a kutatásból kitünik, hogy a fiatalok nincsenek tudatában a koffeintartalmú élvezeti cikkek egészségre káros hatásaival.

Kulcsszavak: koffein; energiaital-fogyasztás; életmód; szakközépiskolai és gimnáziumi diákok

\section{Summary:}

Background: The new trends in consumer behaviour are aligning to the tendency of the radically accelerated things. One of this kind of trend is the appreciation of the time saving products. The purpose of our research was to assess the different types of caffeine consumption and the frequency of use of energy drinks among high school and vocational secondary school students.

Method: The research took place in January and February 2019. As a first step, it was requested the permission from the school directors to allocate the questionnaire. The different question groups of the self-made self-filled questionnaire are socio- 
demographic data, data on caffeine consumption, purchasing habits and lifestyle issues of these products. In addition to descriptive statistical analysis Chi-square test was performed using SPSS.

Results: The average age of the interviewed 180 students was 18.2 years. In terms of gender, girls appeared to be $61 \%$. Based on the responses, it turned out that students in vocational secondary schools consumed more energy drink and much often than high school students. In addition, it also turned out that they were more likely to try new branded energy drinks. In terms of residence, young people living in smaller settlements are characterized by excessive energy drink intake and they are less likely to consider the effects caused by caffeine. Instead, the taste is the main factor that dominates them. Urban students consider coffee as their favourite product in higher rate than their village counterparts do. In case of genders, after processing the data, it can be stated that coffee is more popular among females than males. It is more typical for female gender to get tired faster if they do not drink caffeinated product.

Conclusions: It would be necessary to start educating young people for a healthy lifestyle as early as childhood, as the research shows that adolescents are unaware of the harmful health effects of caffeinated-containing enjoyment items.

Keywords: caffeine; energy drink consumption; lifestyle; vocational secondary school and high school students

\section{BEVEZETÉS}

Az új fogyasztói magatartástrendek igazodnak a gyorsuló események tendenciájához. Az egyik ilyen trend az aktivitást serkentő termékek felértékelődése. ${ }^{1} \mathrm{~A}$ koncentráció és a teljesítőképesség növeléséhez a mindennapokban leggyakrabban a kávét, a fekete teát, a különböző táplálékkiegészítőket és az energiaitalt használják. Ezeknek a fogyasztása a statisztikák szerint növekvő tendenciát mutat: a Központi Statisztikai Hivatal adatai szerint Magyarországon a kávé fogyasztása az elmúlt 45 év alatt 1,6-ról 2,3 kg/fö-re növekedett. ${ }^{2}$ Ennek köszönhető, hogy a piacon újabbnál újabb márkák jelennek meg. A koffein megtalálható számos növényben és termékben is, mint például a tealevélben, csokoládéban, kakaóbabban és a kávébabban is. A világszerte használt pszichostimulánsok közül az egyik legismertebb a koffein, amely nagyon gyorsan felszívódik a szervezetben, és hatása az elfogyasztás után 1 órával tetőzik. Ez a vegyület felelős elsősorban e termékek képességfokozó tulajdonságért. Ahsan és Bashir kutatása szerint a fiatal felnőttek körében a kávé tekinthető az elsődleges koffeinbeviteli forrásnak. Számos előnyének elismerése mellett felhívják a figyelmet a kávéfogyasztás veszéIyeire is: lipidtartalma miatt növeli a szívbetegségek, agyvérzés, szívritmuszavarok és a magas vérnyomás kialakulásának kockázatát. A vizsgálatuk szerint legfeljebb napi 2-3 csésze kávé rendszeres fogyasztása még nem okoz egészségkárosodást. ${ }^{3}$

A fiatal nemzedékek számára az egészséges étkezés és az egészséges életmód oktatása mellett ezzel a témával is foglalkozni kellene, hiszen ha nincsenek tisztában a diákok az élvezeti cikkek hatásaival, nem fogják megtanulni a mértékletességet, és emellett az egészségkockázatok elkerülését sem. Bármilyen koffeintartalmú energiafokozó ételt, italt fogyasztanak, figyelniük kell arra, hogy az egészséges felnőtt szervezet számára 300 mg/nap a maximális ajánlott koffeinmennyiség. Ez körülbelül három csésze kávénak, vagy egy doboz energiaitalnak felel meg. ${ }^{4}$ Rendszeres használatuk felnőtteknek sem ajánlott, fejlődő szervezetnek pedig különösen nem. ${ }^{5}$ Ezen kívül fontos foglalkozni a túlzott cukorbevitellel is, hiszen e termékek nagy mennyiségben tartalmaznak cukrot, amely hozzájárul a túlzott kalóriabevitelhez, ez pedig növeli az elhízás kockázatát.

A vizsgálat célja a középiskolás diákok körében tapasztalt koffeintartalmú italok fogyasztási szokásainak feltárása. A tanulmány a megkérdezett tanulók koffeintartalmú italokkal kapcsolatos ismeretszintjét is vizsgálta, valamint az egészségre gyakorolt negatív hatások ismeretét is feltérképezte. 
A cikk szerzői továbbá rákérdeztek arra, hogy a rendszeres fogyasztók milyen célból isszák ezeket a termékeket, illetve jellemző-e rájuk a márkahűség.

\section{MÓDSZERTAN}

A keresztmetszeti kutatáshoz önkitöltős, saját készítésű kérdőíveket osztottunk ki, melyet a diákok anonim módon töltöttek ki. Mivel a diákok névtelenül töltötték ki a kérdőívet, vélhetően őszinték voltak. A kérdőív hat szociodoemográfiai kérdést tartalmazott, a 7.-11. kérdések az általános koffeinfogyasztás felől tudakozódtak. A 12.-26. kérdések azoknak szóltak, akik rendszeresen fogyasztanak koffeintartalmú italokat, s itt az ő személyes koffeinfogyasztásukra voltunk kíváncsiak. Az utóbbi kérdéscsoport egyaránt tartalmazott nyitott és zárt kérdéseket. A vizsgálati célcsoportot középfokú oktatási intézményekben, gimnáziumban, szakközépiskolában, szakgimnáziumban, szakképző iskolában tanuló 9., 10., 11., 12., 13. osztályos diákok alkották. Az iskolák kiválasztásánál szempont volt, hogy olyan iskolatípust válasszunk, ahol 14 évesnél idősebb fiatalok tanulnak szakmát is adó képzésen. A beválasztási kritériumok közé tartozott, hogy a tanulók középfokú oktatási intézményben, nappali tagozaton 9.-13. évfolyamba járjanak, valamint 14-23 év közöttiek legyenek. A vizsgálat során kizárásra kerültek azok a fiatalok, akik magántanulók, illetve egészségügyi probléma miatt nem fogyaszthatnak koffeintartalmú készítményeket. Ilyenek például a magas vérnyomásban szenvedők, koffeinérzékenyek és a szívbetegek. Khi-négyzet próbával és Fisher's Exact teszt segítségével elemeztük a változók közötti kapcsolatokat. Szignifikánsnak tekintettük az eredményeket, amennyiben $p \leq 0,05$.

A kereskedelemben leggyakrabban előforduló termékek nevét zárt kérdés formájában felsoroltuk, amelyek közül a tanulók többet is bejelölhettek. A cikkben ismertetett eredmények csak a fenti két iskolában tanuló és a kérdőívet kitöltő diákok koffeintartalmú italok fogyasztását mutatja be, az eredmények a hazai középiskolásokra nem általánosíthatók. A kérdőív segítségével választ kaptunk arra is, hogy a diákok mit gondolnak a koffeines italok hatásáról. A kérdés során azt a választ kellett bejelölniük, amely szerintük a leginkább igaz.
A kutatásban érintett oktatási intézmények:

- a Kiskőrösi Petőfi Sándor Evangélikus Óvoda, Általános Iskola, Gimnázium és Szakgimnázium;

- a kaposvári Kinizsi Pál Élelmiszeripari Szakközép és Szakképző Iskola volt.

Az adatgyűjtést 2019. január és február hónapban végeztük.

A feltett kérdések száma összesen 26, melyből 24 kérdés volt zárt, és 2 kérdés nyitott. A főbb kérdéscsoportok az alábbiak voltak:

- személyes adatok (nem, életkor, lakhely, iskolatípus, évfolyam, szülők iskolai végzettsége);

- koffein-fogyasztással kapcsolatos kérdések (fogyaszt-e koffeintartalmú italokat, milyen típusokat, mely napszakban, fogyasztás gyakorisága, tapasztalt hatásuk, tudásszint-felmérés a túladagolás lehetőségéről, valamint a napi biztonsággal fogyasztható mennyiségről;

- koffeines termékekkel kapcsolatos vásárlási szokások;

- életmódra vonatkozó kérdések.

Az eredmények feldolgozásánál a diákokat iskolatípus szerint két csoportba osztottuk:

- szakmai képzést adó középiskolák (szakközépiskola, szakgimnázium, szakképző iskola): a továbbiakban az egyszerűség kedvéért „szakközépiskola";

- szakmai képzést nem adó középiskola: a továbbiakban „gimnázium”.

A korcsoportok felosztásánál a különböző iskolatípusokra jellemző végzős életkorokat tekintettük felső határnak.

\section{EREDMÉNYEK}

Az kitöltött kérdőívek száma összesen 208 volt. $A z$ értékelhetetlen vagy hiányos válaszok kizárása után 180 db kérdőív adatai kerültek elemzésre, ebből 110 lány és 70 fiú volt. A kutatás azon pontjáig minden kitöltő válaszait figyelembe vettük, amíg a diákok a saját koffeinfogyasztásukról nem nyilatkoztak. Ezután értelemszerúen már csak azok a fiatalok válaszait dolgoztuk fel, akik úgy nyilatkoztak, hogy fogyasztanak koffeines italokat. A továbbiakban 
szereplő százalék-értékek tehát a 170 fős mintára vonatkoznak.

A kérdőívek kitöltése során a nemek hasonló arányban oszlottak meg: a kitöltők 61\%-a volt lány, 39\%-a pedig fiú. A legfiatalabb válaszadó 14 éves, a legidősebb 23 éves. Az átlagéletkoruk 18,2 év. [1. ábra]

A válaszadók 28\%-a 14-16 év közötti, 54\%-a 17-18 év közötti, 18\%-a pedig 19-23 év közötti volt. [2. ábra]
A megkérdezett tanulók 59\%-a szakközépiskolában, 41\%-a gimnáziumban végezte tanulmányait.

Lakhely szerinti megoszlás a következő volt: a kérdőívet kitöltők 41\%-a városban, míg 59\%-a községben vagy faluban él.

A szülők iskolai végzettségét nézve a legnagyobb arányban azok a diákok szerepeltek, akiknek a szülei érettségivel vagy felsőfokú szakképzettséggel rendelkeznek, de főiskolával, illetve egyetemmel nem. [3. ábra]

1. ábra: A válaszadók életkor szerinti megoszlása $(n=180)$

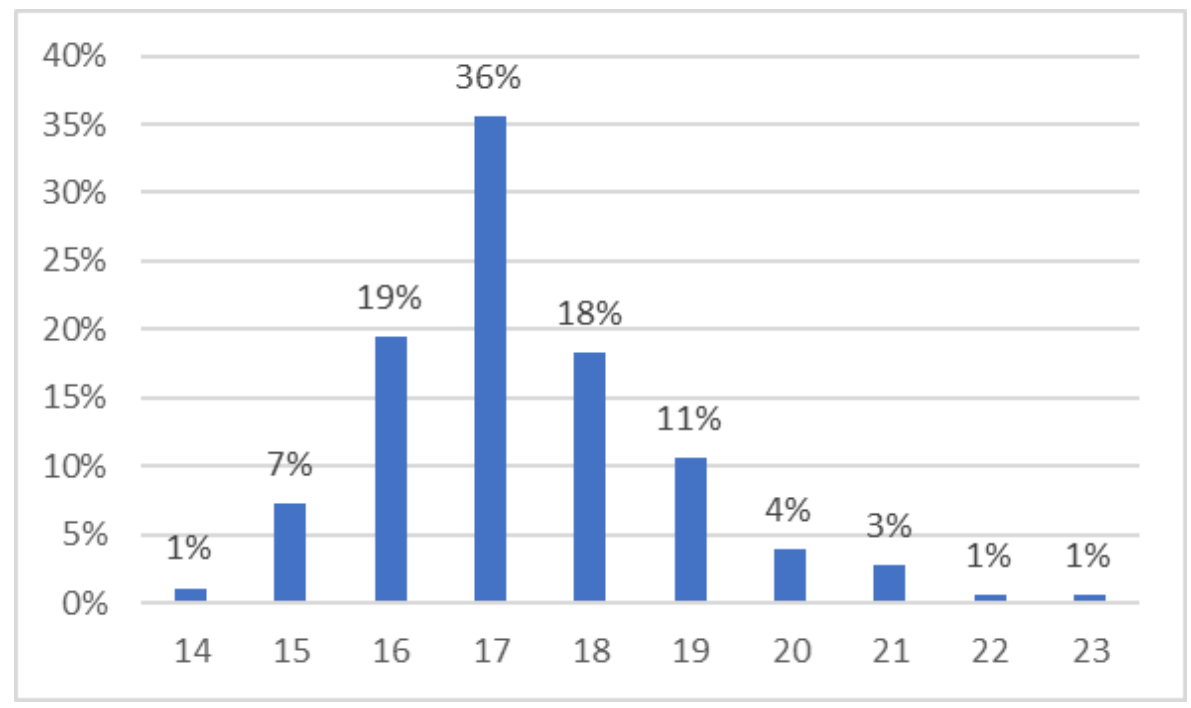

Forrás: saját szerkesztés

2. ábra: A válaszadók korcsoport szerinti megoszlása ( $n=180$ )

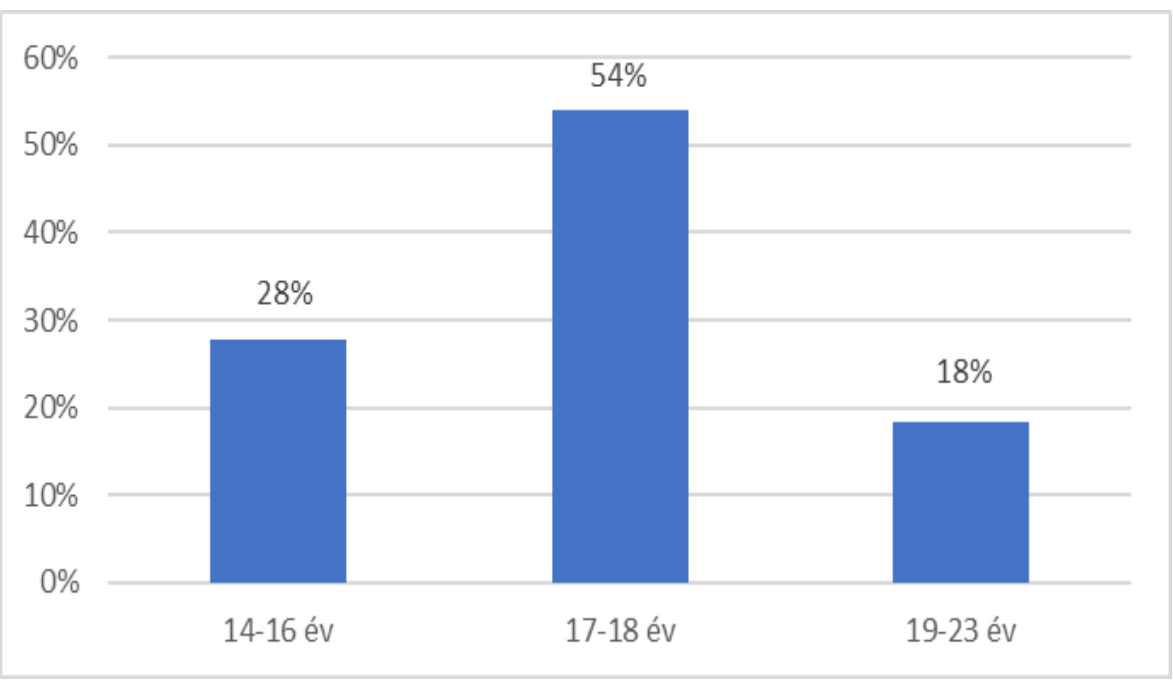

Forrás: saját szerkesztés 
3. ábra: A szülók iskolai végzettségének megoszlása ( $n=180)$

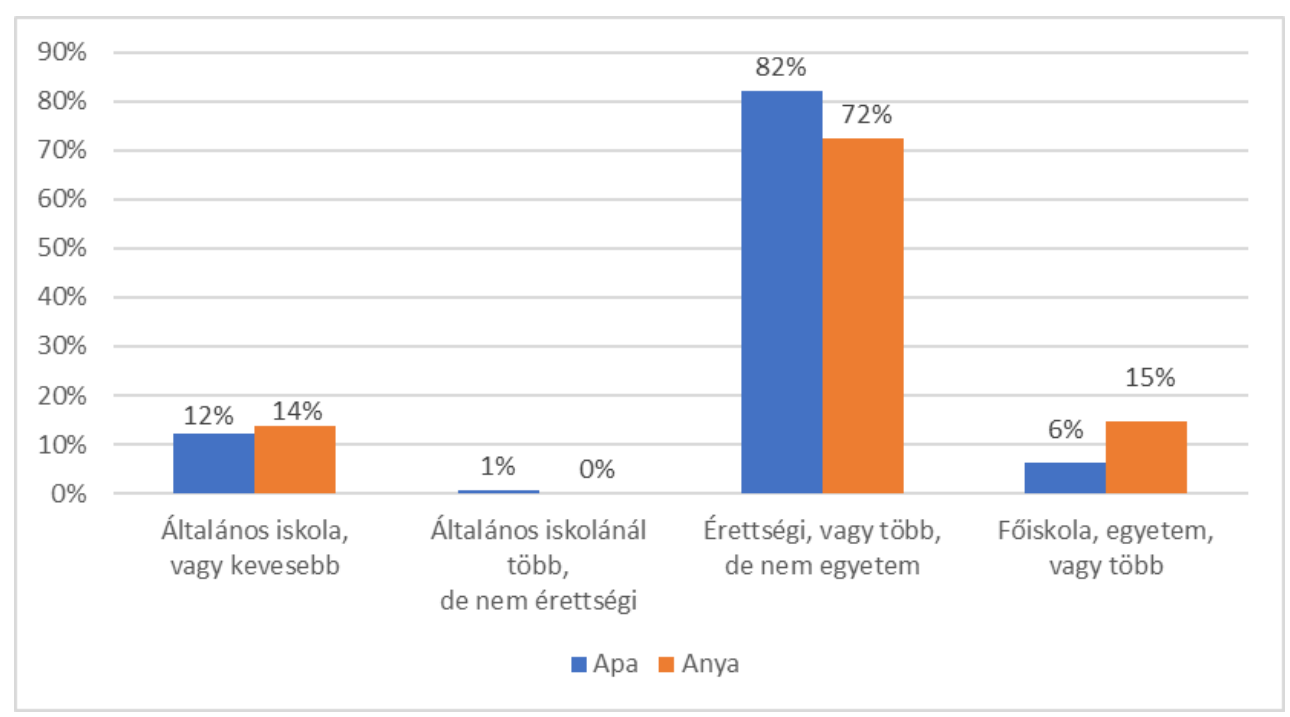

Forrás: saját szerkesztés

A mintában részt vevők viszonya

a koffeintartalmú italokhoz

Arra a kérdésre, hogy fogyasztottak-e valaha koffeintartalmú italokat, a diákok túlnyomó része (94\%) válaszolt igennel. A nemmel válaszolók száma 6\%-ot tett ki, ez 10 főt jelentett a teljes mintából. Ezeket a diákokat a koffeines italok tudatos kerülésének okáról is kérdeztük. 2 fő válaszolta, hogy ő nem kedveli az ilyen italok ízét, míg 7 fő szerint egyáltalán nincsen szükségük e termékek fogyasztására. Mindössze 1 válaszadó jelezte, hogy fél a túlzott fogyasztás okozta egészségügyi következményektől.

A vizsgálat során feltérképeztük, hogy a megkérdezettek mit tudnak a még biztonsággal fogyasztható napi koffein mennyiségről. A tanulók több mint a fele (57\%) vélte úgy, hogy ha elfogyaszt 2 presszó kávét naponta, az még nem ártalmas a szervezet számára. A minta másik része (43\%) pedig teljesen megosztott ebben a témában. [4. ábra]

4. ábra: Szerinted mennyi a napi még biztonsággal fogyasztható mennyiség? ( $n=180)$

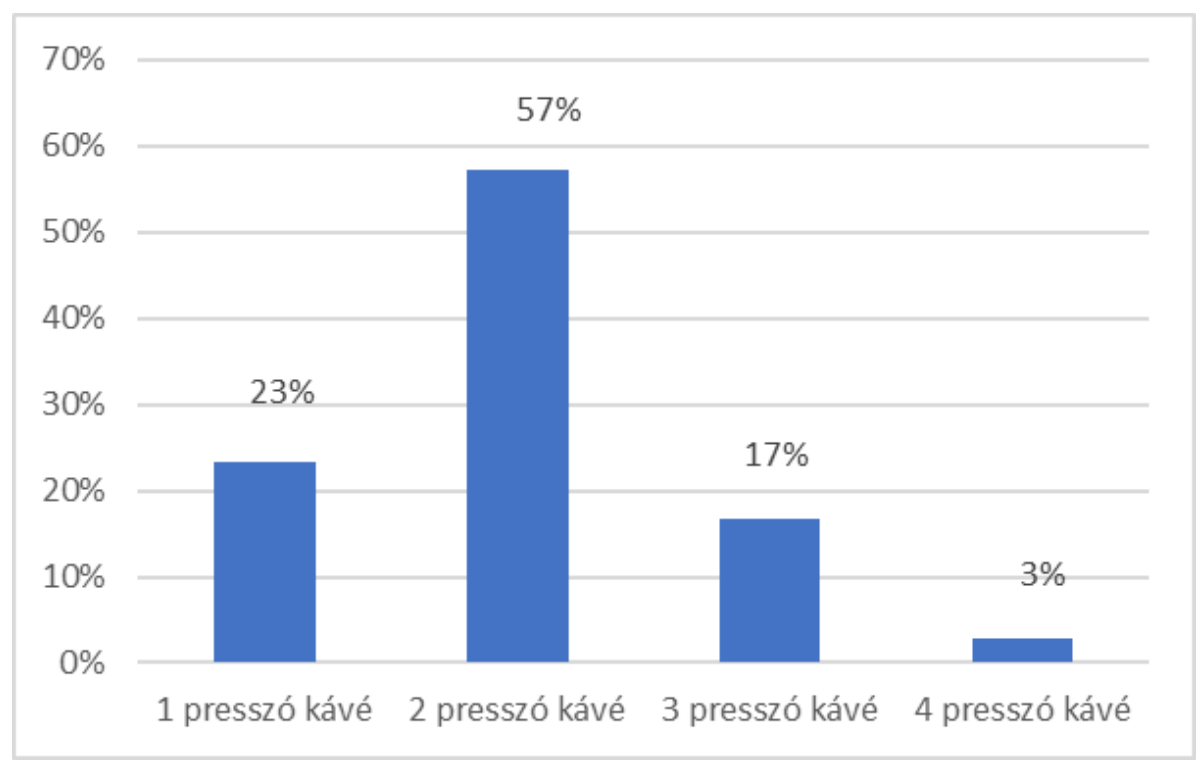

Forrás: saját szerkesztés 
További kérdésként a vizsgálatban részt vevők arra a kérdésre válaszoltak, hogy szerintük túl lehet-e adagolni a koffeint. A fiatalok túlnyomó része (83\%) nyilatkozta, hogy igen, túlzásba lehet vinni a koffeinfogyasztást. Ezzel szemben a 6\%-uk gondolta úgy, hogy ez nem lehetséges, 11\%-uk pedig a „nem tudom" választ jelölte be.

A mintának csupán a 37\%-a vélte úgy, hogy nagymértékben káros a szervezetükre, ezzel szemben $58 \%$ jelölte a kevésbé káros választ. A nemmel válaszolók aránya $5 \%$ volt.

\section{Koffeintartalmú italok fogyasztása}

A leggyakoribb fogyasztási cikk helyén a kóla szerepel 92\%-kal. A második helyet a kávé foglalta el 85\%-os válaszaránnyal, majd ezeket szorosan követte az energiaital 78\%-kal. A fekete tea esetében kiderült, hogy a diákok nagyobb része (63\%) nem fogyasztotta rendszeresen. A lista legalján szerepelt a koffein tabletta, melynek fogyasztása nem volt jellemző a diákok körében. A válaszadók közül csupán 3 személy (2\%) fogyasztotta már élete során. [1. táblázat]

1. táblázat: Koffeintartalmú italok fogyasztása $(n=180)$

\begin{tabular}{|ccccccc}
\hline & Kávé & Fekete tea & Energiaital & Kóla & Sportital & $\begin{array}{c}\text { Koffein } \\
\text { tabletta }\end{array}$ \\
\hline $\begin{array}{c}\text { A válaszadók hány } \% \text {-a } \\
\text { fogyasztotta }\end{array}$ & $85 \%$ & $37 \%$ & $78 \%$ & $92 \%$ & $27 \%$ & $2 \%$ \\
\hline
\end{tabular}

Forrás: saját szerkesztés

A résztvevők válaszoltak azon kérdésre is, hogy a koffeintartalmú italok elfogyasztása után tapasztaltak-e pozitív, illetve negatív hatást. Vizsgálatunk során a koffeines italokat fogyasztó válaszadók 69\%-ánál jelentek meg a kellemetlen tünetek. Rákérdeztünk az elfogyasztás után kialakult fokozott energianövekedésre is. A diákok válaszai közel fele-fele arányban oszlottak meg, 53\% vélte úgy, hogy tapasztalta már ezt az érzést, míg 47\%-uk nem érzett ilyen problémát.
Negatív hatásként megemlíthető a fokozott szívdobogás-érzés, de a válaszok alapján mindössze 46 fő (27\%) tapasztalta ezt az élete folyamán. A remegés előfordulása csak minimálisnak volt tekinthető a 9\%-kal. A minta 26\%-a érzett kialvatlanságot az elfogyasztást követően. A gyomorfájdalom érzésére adott válaszok száma nem volt számottevő.

$\mathrm{Az}$ energiaital esetében teljesen más arányokat tapasztaltunk. A nem fogyasztók aránya 17\%, magasabb volt, mint a kávénál. A heti, illetve havi fogyasztás mértékét az alábbi diagram mutatja be. [5. ábra]

5. ábra: Milyen gyakran fogyasztasz energiaitalt? ( $n=170)$

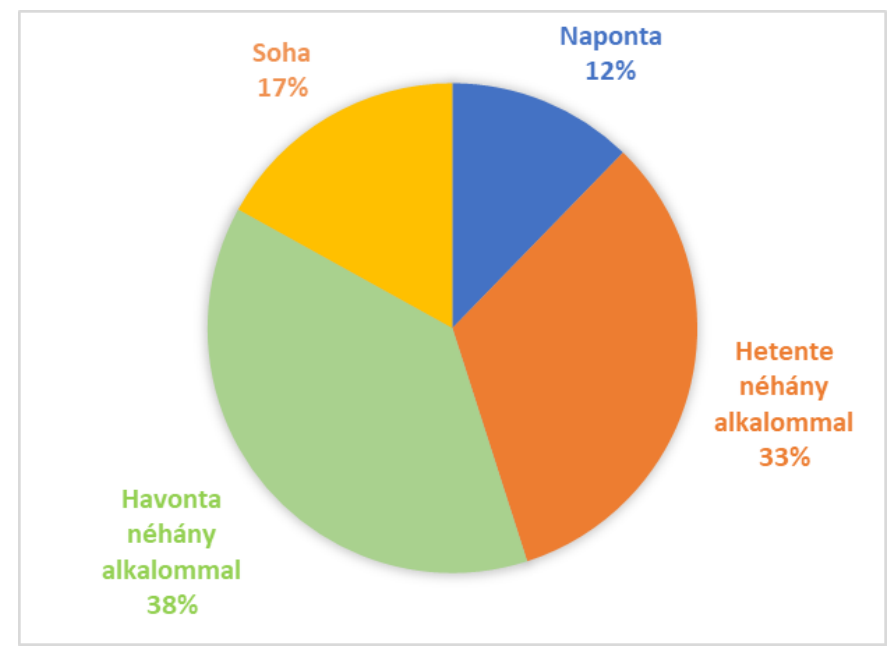

Forrás: saját szerkesztés 
A különféle élvezeti cikkek fogyasztását vizsgálva észrevehető volt, hogy minden termék esetében a "hetente 1-2 alkalommal”, illetve a "havonta 2-3-szor vagy ritkábban" kategória vezetett. A kólafogyasztást tovább vizsgálva azt tapasztaltuk, hogy a diákok 24\%-a napi szinten megvásárolta, míg 2\%-a soha nem fogyasztott ilyen terméket. Az a 3 fő (1\%), aki használt koffein tablettát, egységesen azt válaszolta, hogy havonta 2-3 alkalommal, vagy még annál is ritkábban élt vele. [2. táblázat]

Arra a kérdésre, hogy mely napszakban szokták fogyasztani a koffeines termékeket, elég egybehangzó válasz született. 95\%-ban napközben használták ezen italokat, amely magába foglalta a délelőtti és délutáni fogyasztást is. 2\%-ban kizárólag az esti fogyasztás volt jellemző, illetve 3\%-uk szerint a nap bármely szakaszában megesett egy-egy ital elfogyasztása.

2. táblázat: Koffeintartalmú termékek fogyasztási gyakorisága

\begin{tabular}{cccccc}
\hline & Kávé & Energiaital & Kóla & Sportital & $\begin{array}{c}\text { Koffein tab- } \\
\text { letta }\end{array}$ \\
\hline $\begin{array}{c}\text { Naponta } \\
\text { Hetente néhány } \\
\text { alkalommal }\end{array}$ & $32 \%$ & $12 \%$ & $14 \%$ & $1 \%$ & $0 \%$ \\
$\begin{array}{c}\text { Havonta néhány } \\
\text { alkalommal, vagy ritkábban }\end{array}$ & $25 \%$ & $32 \%$ & $39 \%$ & $5 \%$ & $0 \%$ \\
\hline Soha & $9 \%$ & $38 \%$ & $45 \%$ & $23 \%$ & $2 \%$ \\
\hline
\end{tabular}

Forrás: saját szerkesztés

A kérdőív során kitértünk az energiaital márkákra is. Ezt a kérdést csak azok a személyek töltötték ki, akik fogyasztanak ilyen italokat. Vizsgáltuk, hogy van-e olyan márka, amelyet kimagaslóan sokan választanak, vagy egyenletes az eloszlási arány.

Az eredmények alapján látható, hogy kimagaslóan vezetett a Hell márka, 41\%-kal. Így maga mögé utasította mind a Red Bullt, mind a Monstert. A válaszadók második kedvenc márkának jelölték a Bombát, 17\%-kal. A többi márkatípus esetében nem tapasztaltunk jelentős eltérést. 1 személy $(0,7 \%)$ választotta az egyéb kategóriát, neki a Rock star nevezetû energiaital volt a kedvence. [6. ábra]

6. ábra: Melyik energiaitalt fogyasztod leggyakrabban? ( $n=141)$

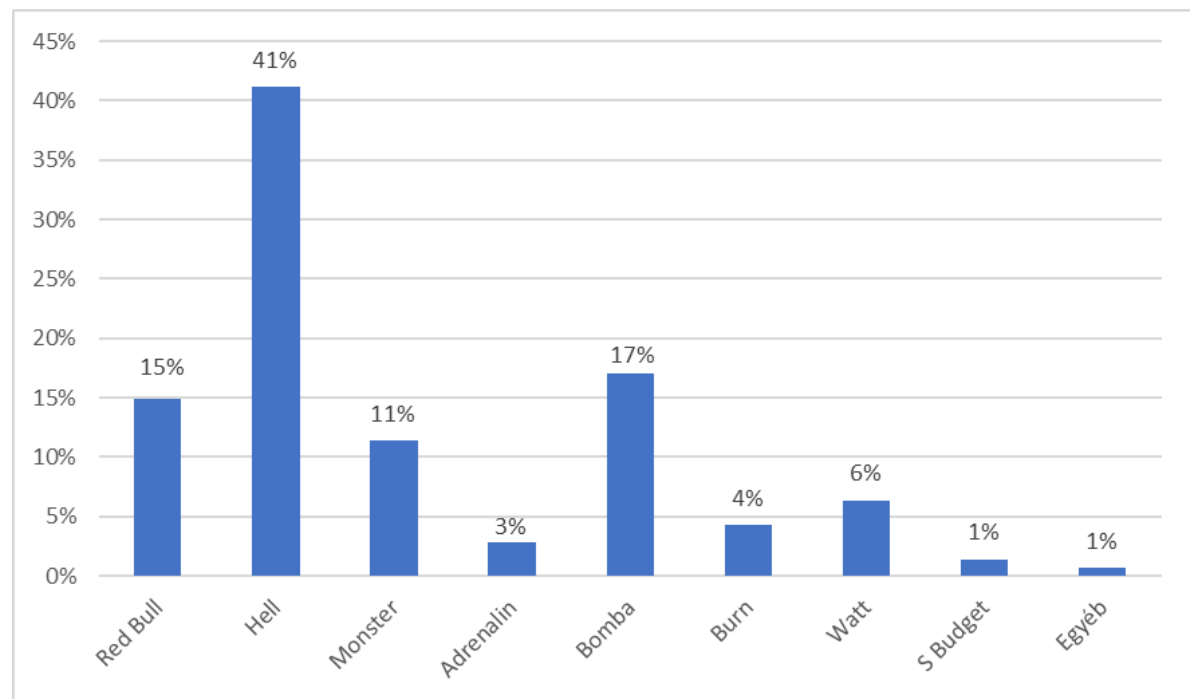

Forrás: saját szerkesztés 
A termékválasztás vizsgálata során kimutattuk, hogy szignifikáns $(p=0,003)$ kapcsolat állt fenn a nemek és a preferált koffeines termékek között. A lányok $58 \%$-a jelölte meg a kávét kedvenc koffeines terméknek, míg a fiúknak csak 42\%-a. A fekete tea esetében számottevő különbséget lehetett megfigyelni a nemek között. A válaszadók közül a lányok 94\%-kal vezettek, a fiúk alig 6\%-kal követték őket. Az energiaitalt szintén a lányok itták szívesebben, bár a különbség csak 8\%. A kóla esetében közel kétszeres volt az eltérés, a lány diákok 68\%-kal túlnyomó többségben voltak. ${ }^{6}$ [7. ábra]

7. ábra: Melyik koffeintartalmú italt kedveled? (n=166)

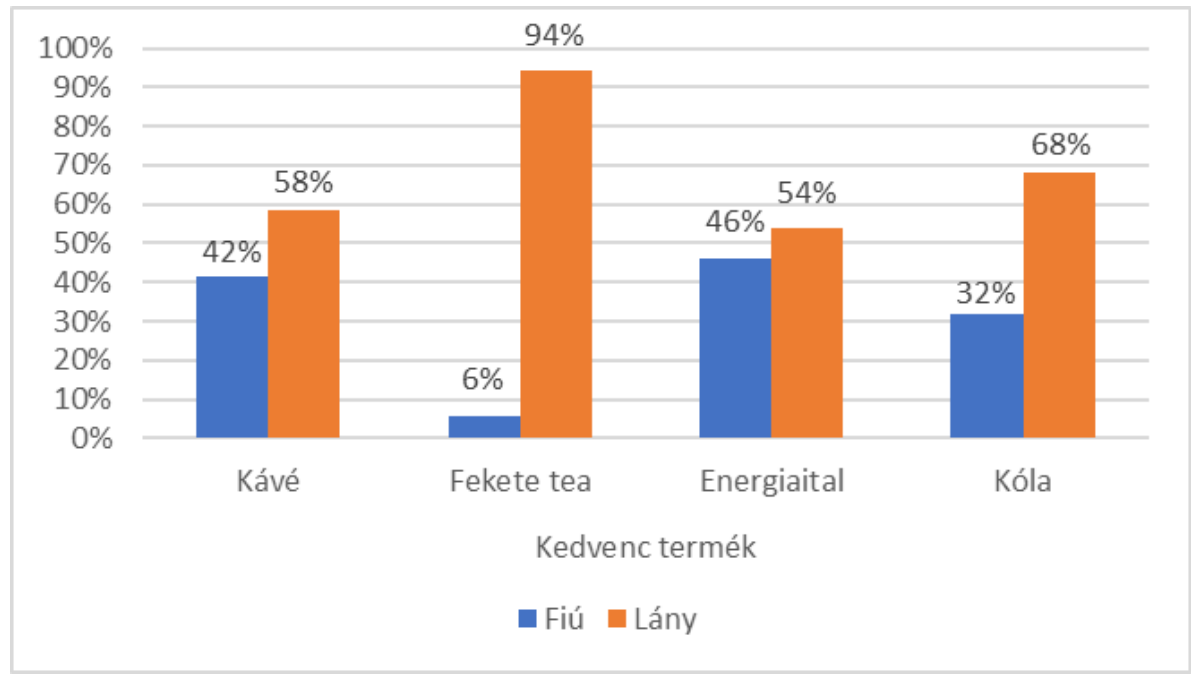

Forrás: saját szerkesztés

\section{Koffeintartalmú italok vásárlási szokásai}

A felmérésben részt vett tanulók 29\%-a saját bevallása szerint havi szinten 500,- Ft-ot vagy kevesebbet költött energiaitalra, kávéra, kólára. A legtöbben (34\%) az 500 és 1.000,- Ft közötti csoportba sorolták magukat. Azon fiatalok, akik nagyobb mennyiségben éltek e cikkekkel, ők 1.000-2.000,- Ft-ot szántak erre minden hónapban, a rendszeresen fogyasztók pedig akár 2.000,- Ft feletti összeget is fordítottak erre.

8. ábra: Iskolatipusok energiaital fogyasztásának megoszlása ( $n=180$ )

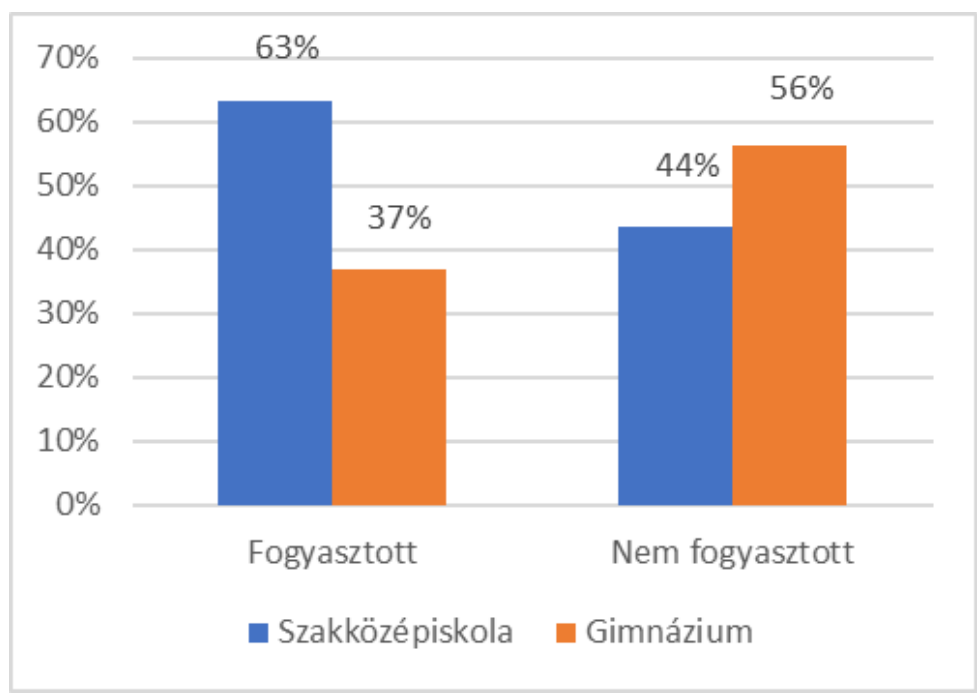

Forrás: saját szerkesztés 
A kitöltők 33\%-a nyilatkozott úgy, hogy ha a piacra kerül valamilyen új márkájú energiaital, szívesen megkóstolná. A 64\%-uk nem gondolt arra, hogy otthonra tartalékba vegyen energiaitalt. A maradék 3\%-nál pedig a lista első helyén szerepelt ez a termék.

A két eltérő iskolatípus - gimnázium és szakközépiskola - diákjai között felmértük az energiaital fogyasztási szokásokat. Az adatokat összehasonlítva szignifikáns kapcsolat mutatkozott $(p=0,042)$. Jól kirajzolódott, hogy a szakközépiskolás tanulók jóval nagyobb arányban (84\%) fogyasztották e terméket. A gimnáziumban ezzel szemben csak a 70\%-uk élt ilyen élvezeti cikkel. ${ }^{7}$ [8. ábra]

\section{Koffeinfüggőség felmérése}

Arra a kérdésre, hogy saját bevallás alapján koffeinfüggőnek tartja-e magát, jelentős eltérés volt megfigyelhető. A kitöltők 5\%-a a „nem tudom” választ jelölte be, $4 \%$ pedig függőnek ítélte magát, ők nem tudják elképzelni a napjaikat koffein nélkül. 19\%-uk szerint ők nem függők, bármikor abba tudták volna hagyni a fogyasztást, de nem akarták. A megkérdezettek $66 \%$-a pedig bármikor tudta volna nélkülözni a koffeint.

A statisztikai próba elvégzése után egyértelmúvé vált, hogy a tényezők közötti kapcsolat szignifikáns volt ( $p=0,001)$, a kisebb települések vizsgált fiataljai inkább energiaitalt fogyasztottak, a városokban inkább jellemző volt a kávéfogyasztás. A kisebb településen élő, általunk vizsgált középiskolás diákoknak több mint a 90\%-a nyilatkozta azt, hogy rendszeresen fogyasztja az energiaitalt. Mindösszesen 6 fő volt (a falun élő diákok 6\%-a), aki elmondása szerint soha nem nyúlt ehhez az élvezeti cikkhez. A városban is nagy arányban találtunk energiaital fogyasztókat, de e településtípuson már nagyobb arányban vezetett a soha nem fogyasztó diákok csoportja. A gyakoriság mértékét tovább taglalva megfigyeltük, hogy azok a megkérdezett személyek, akik a városban laknak, jellemzően havonta 2-3 alkalommal, vagy még annál is ritkábban éltek ezzel az itallal, amely alapján kijelenthető, hogy nem tartoztak a gyakori fogyasztók körébe. A kisebb településen élő, általunk megkérdezett fiatalokról ezt már nem lehetett állítani, hiszen a legnagyobb arányban azt válaszolták a kérdőívben, hogy ők hetente 1-2 alkalommal megvették maguknak ezeket az italokat. A hetente 3-nál többszöri fogyasztók közel azonos arányban oszlottak meg a két településtípus fiataljai között. A városi diákok közel 7\%-a napi rendszerességgel fogyasztotta az energiaitalt, ezzel szemben a vidéken élők csaknem háromszor annyian (19\%) nyilatkoztak hasonlóképpen. [9. ábra]

9. ábra: Lakhely és az energiaital fogyasztásának gyakorisága közötti összefüggés ( $n=170)$

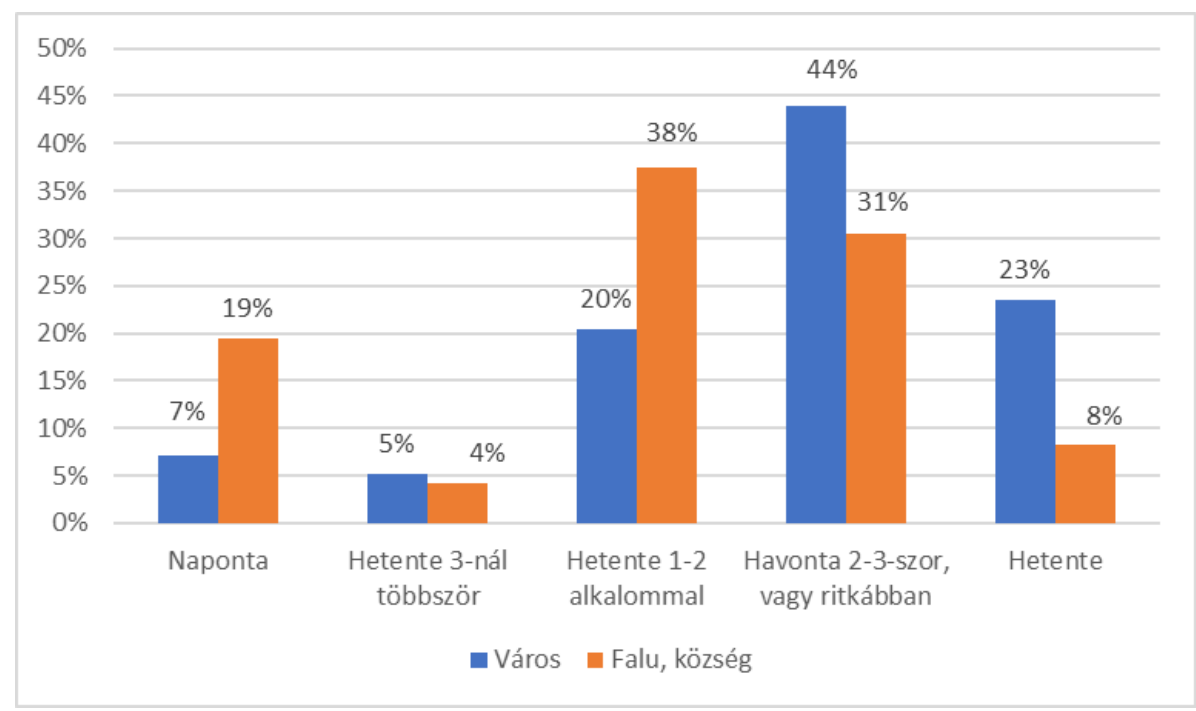

Forrás: saját szerkesztés 
Szignifikáns kapcsolat mutatkozott abban is, hogy a városban lakók nagyobb arányban részesítik előnyben a koffeines italok fizikai-szellemi képességnövelésének hatását, mint a falun élő fiatalok. A termék íze esetében különbséget nem lehetett felfedezni, hiszen a két településtípus lakói megegyező arányban, 51\%-ban fogyasztották az íze miatt (is) a termékeket. [10. ábra]
Kutatásunk során bebizonyosodott $(p=0,02)$, hogy azok a tanulók, akik feszültek, idegesek és ingerültek voltak, ha nem volt koffeines termék a közelükben, jellemzően (85\%) szakközépiskolába jártak. A két iskola tanulói között nem volt számottevő eltérés (54\% - 46\%) abban a kategóriában, ahol a bevallásuk szerint eszükbe sem jutott a fogyasztás, ha ez véletlenül elmaradt valamilyen okból. [11. ábra]

10. ábra: Miért fogyasztod elsősorban a koffeintartalmú italokat? ( $n=170)$

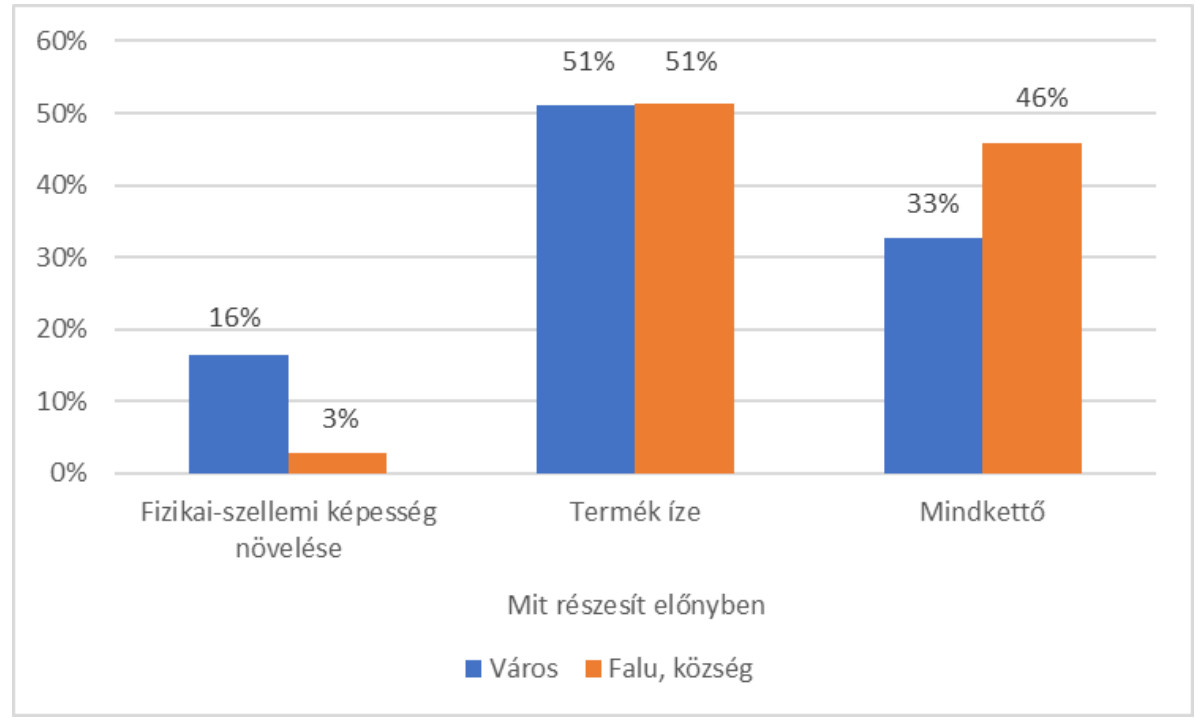

Forrás: saját szerkesztés

11. ábra: Mit érzel, ha nem fogyasztottál koffeines terméket? ( $n=170)$

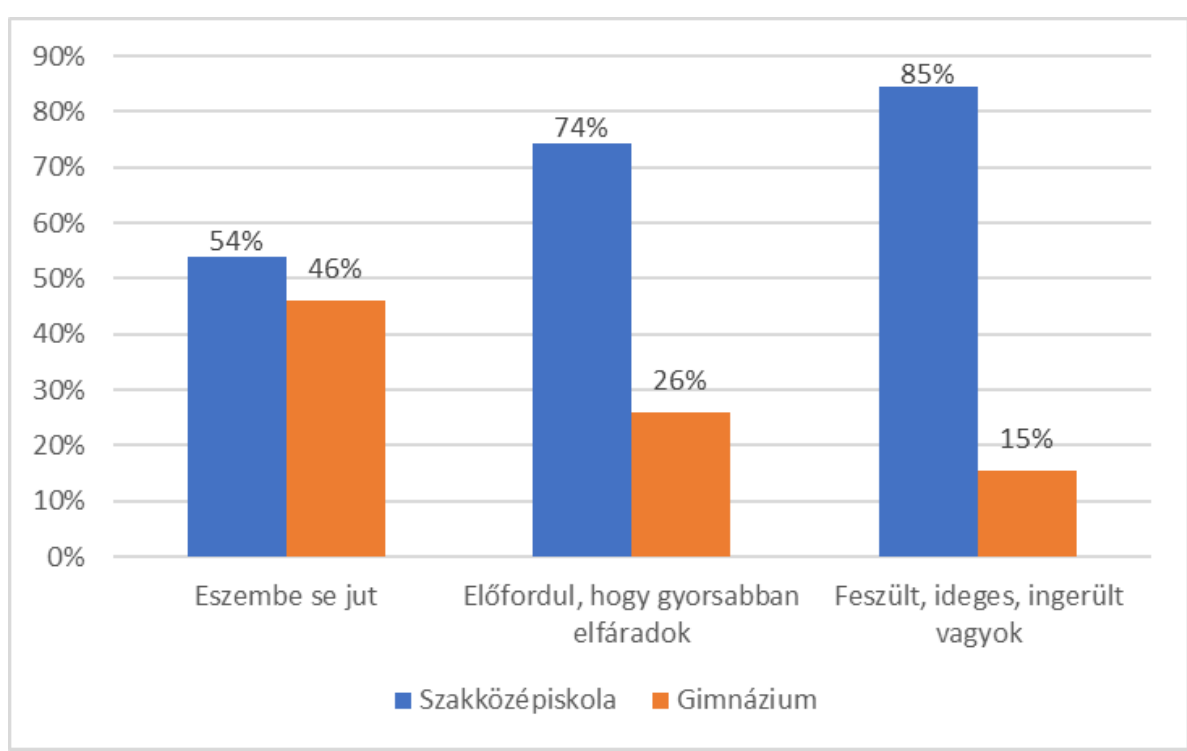

Forrás: saját szerkesztés 
Eredményeink azt mutatják, hogy a szakközépiskolába járó diákok gyakrabban fogyasztottak energiaitalt $(p=0,004)$, mint a gimnáziumba járók. Azon diákok, akik napi szinten magukhoz vették az energiaitalokat, nagy része szakközépiskolába járt. A hetente 3-nál több alkalommal fogyasztók esetében is hasonló arányt találtunk. A hetente 1-2 alkalommal kategória már nagyobb mértékben osztotta meg a mintát, míg a havonta 2-3-szor vagy ritkábban válasz esetében szinte kiegyenlítődtek az arányok a diákok között. A gimnáziumi fiatalok 48\%-ban jelölték be válaszként, míg a szakközépiskolások 52\%-ban. Az energiaitalt soha nem fogyasztó válaszolók megoszlását tekintve $55 \%$ volt gimnazista, míg 45\% szakközépiskolás diák. [12. ábra]

12. ábra: Milyen gyakran fogyasztasz energiaitalt? $(n=170)$

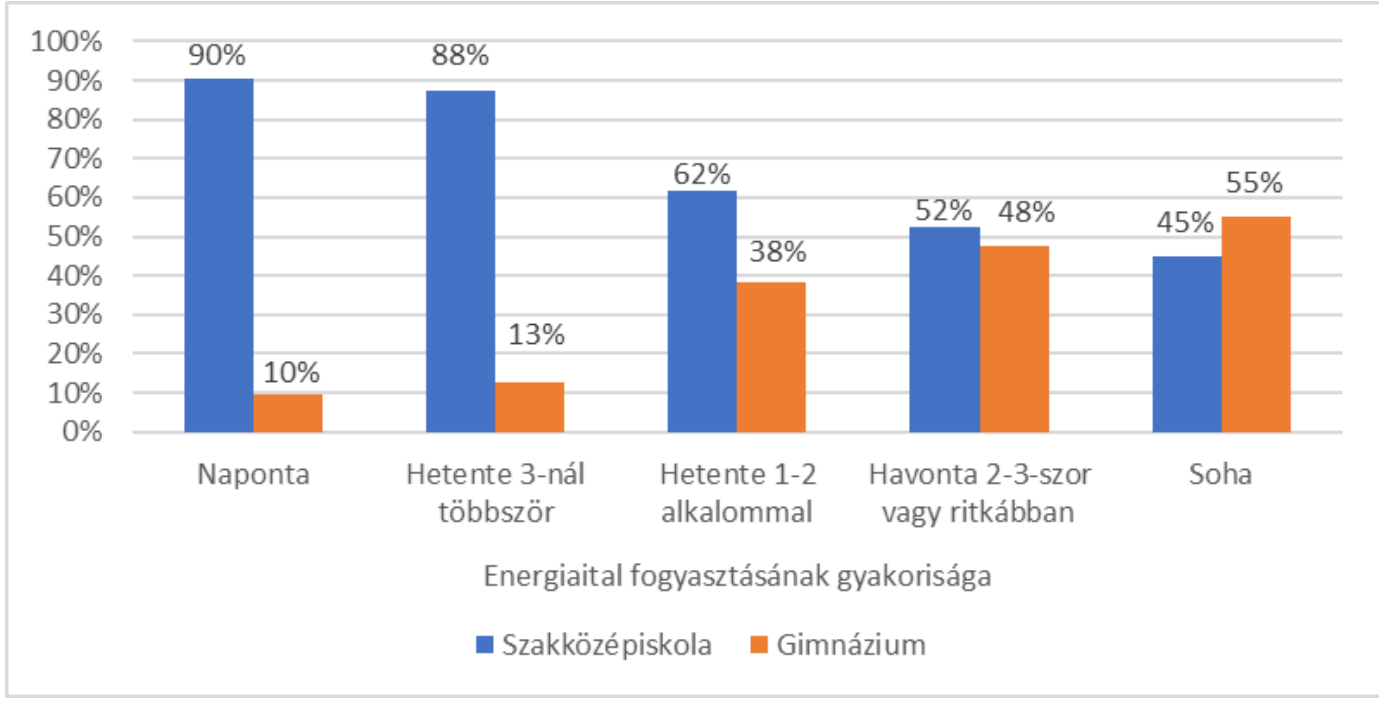

Forrás: saját szerkesztés

13. ábra: Településtípusok és a kedvenc termékek közötti összefüggések (n=166)

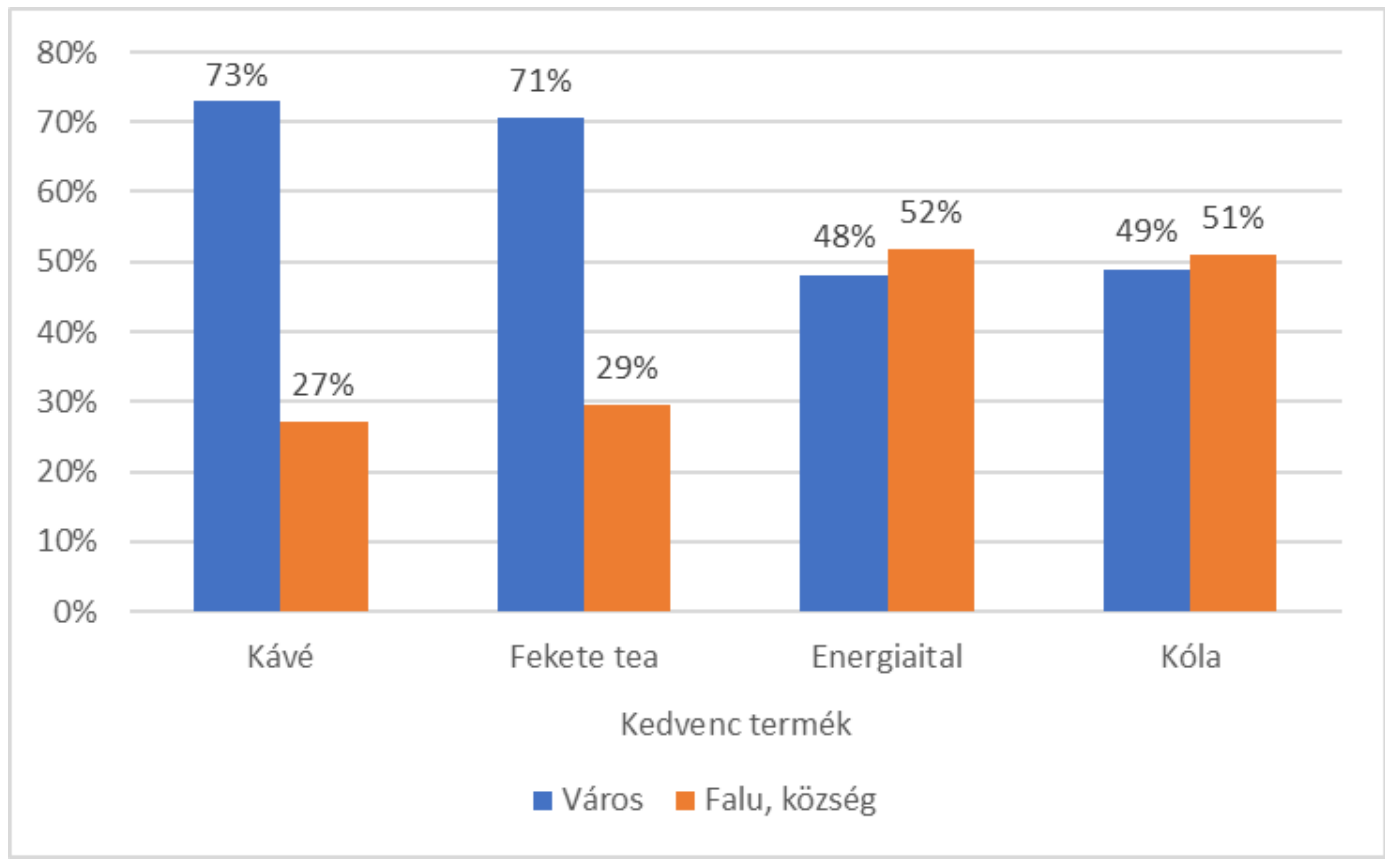

Forrás: saját szerkesztés 
Egyértelmú szignifikáns kapcsolat volt kimutatható a településtípus és a kávéválasztás között $(p=0,041)$. Szembetűnő volt, hogy a városi diákok jóval nagyobb arányban (73\%-ban) válaszolták azt, hogy a kávét tartották kedvenc koffeines terméknek. A falvakban élőknek csupán a $27 \%$-a nyilatkozott hasonlóan. Ezzel szemben az energiaitalt tekintve inkább a vidéki fiatalok kedvelték ezt a terméket.

Százalékos eloszlását nézve nem volt látható olyan nagymértékű eltérés a két településtípus között. Hasonló volt a helyzet a kóla esetében is, hiszen mindössze $2 \%$-kal voltak lemaradva a városi fiatalok a vidékiektől. A fekete tea esetében már nagyobb eltérés volt látható a diagramon is. A nagyobb településen élő tanulók jóval többen választották kedvenc koffeines termékként a fekete teát. ${ }^{8}$ [13. ábra]

\section{MEGBESZÉLÉS}

\section{Eredmények összefoglalása}

Kutatásunk során két eltérő iskolatípus tanulói között mértük fel a koffeintartalmú italokkal kapcsolatos fogyasztási szokásokat. A vizsgálat célja az volt, hogy képet kapjunk a diákok koffeinfogyasztásáról. Szerettük volna megtudni, hogy a rendszeres koffeinfogyasztók mi alapján döntenek a vásárlások alkalmával, illetve jellemző-e rájuk a márkahűség. A kutatás alapján megállapítottuk, hogy a megkérdezett fiatalok többsége napi szinten fogyasztotta energiaitalt. Az ital íze fontos fogyasztási tényező, 51\%-uk ezért is vásárol ilyen terméket. Emellett az ital hatása, a fizikai-szellemi képesség serkentése is számít 11\%-uknál. Ha mindkét említett tényezőt figyelembe vesszük, a vizsgált fiatalok 38\%-a ezen okok miatt vásárol energiaitalt. Ez azért is sajnálatos, mert az energiaitalok voltaképpen cukros üdítőitalnak számítanak, amelyek nem az egészséges táplálkozást támogatják.

A magyar mintában a rendszeres fogyasztó fiatalok aránya (napi ill. heti három napnál gyakrabban) $17 \%$ volt. A fiatalok gyakran nem ismerik az általuk fogyasztott élvezeti cikkek veszélyeit, egészségkárosító hatásait. A vizsgált diákok többsége akkor is fogyasztja a terméket, ha annak használata nem kívánt tüneteket okoz.

\section{A vizsgálat korlátai - limitációk}

A kutatás korlátjának tekinthető az a tény, hogy a kérdőívet az általunk választott iskolák tanulói töltették ki, a minta beválasztási kritériumai tehát irányított módon kerültek meghatározásra, amely alapján általánosításra nem volt használható.

\section{Az eredmények értelmezése}

Emond és munkatársainak kutatása alapján az amerikai 18-21 éves fiatalok körében 68\%-os arányban a férfiak kedvelik jobban az energiaitalokat. 61\%-a preferálja a különböző márkájú termékek közül a Monster-t, míg a Red Bullt pedig az 57\%-a. A fogyasztók több mint a fele azért választja ezeket a termékeket, mert élvezik az ízét. A másik 50\%-a pedig azért használja, mert javítja a koncentráló képességüket. Többnyire 1 italnál kevesebbet isznak meg egy héten, míg a 29\%-a 1-2-t fogyaszt hetente. Kutatásunkban az energiaitalt a lányok fogyasztották szívesebben, az íz tekintetében azonban a vizsgált magyar fiatalok is hasonlóképen vélekednek, többségük az íze miatt fogyasztja elsősorban a fenti termékeket. ${ }^{9}$

Costa, Hayley és Miller tanulmányában ausztrál fiatalok energiaital fogyasztását vizsgálta. A fogyasztók 53,2\%-a számolt be arról, hogy legalább egy fiziológiás tünetet észleltek a felsoroltak közül az energiaital után. 25\%-uk tapasztalta az "egyéb” tüneteket, melyek közé sorolták a szédülést, puffadást, fáradtságot, energiacsökkenést. ${ }^{5}$

Saját kutatásunk során eltérő eredményekre jutottunk. Az általunk vizsgált fiatalok körében az energiaitalt a lányok isszák magasabb arányban (62\%), míg a fiúk csupán 38\%-ban.

Vas megyei 13-18 éves fiatalok ( $n=197)$ körében végzett kutatási eredmény alapján a tanulók napközben érzett fáradtsága és a koncentrálóképesség csökkenése erőteljes (60,4 \%), ami indokolttá teheti a koffeintartalmú italok fogyasztását. ${ }^{10}$

Malinauskas és társai kutatásában a válaszadók 29\%-a tapasztalt heti rendszerességgel gyomorpanaszokat, míg 19\%-a erős szívdobogást a koffein hatása miatt. A fiatalok $65 \%$-a érzi, hogy sokkal több energiája van tôle. Angol és francia nyelven beszélők között történt a felmérés. 2040 kérdőív került kitöltésre, ebből 21,8\%-ukra lehet azt állítani, hogy 
ők rendszeres fogyasztók. Nem volt nagy különbség az angol és a francia nyelven beszélők között. Az örökös fogyasztók közül 16\%-a válaszolta azt, hogy naponta több mint kettő dobozzal iszik. Arra a kérdésre, hogy milyen ok áll az úgynevezett függőség hátterében, több válasz érkezett. Vannak, akik az íze miatt, a növekedett koncentráció képesség miatt, kíváncsiságból fogyasztják. ${ }^{6}$

Saját vizsgálatunkban a megfigyelt szempontok a következőképen alakultak. Az energiaital fogyasztó fiatalok közül 27\%-uk szívdobogásról, 9\%-9\%-uk szédülésről és remegésről, 8\%-uk gyomorfájdalomról, 53\%-uk pedig megnövekedett energiaszintről számolt be.

\section{KÖVETKEZTETÉSEK}

A kutatás új fogyasztási trendre hívja fel figyelmünket, mely a középiskolás diákok körében is elterjedni látszik. A koffeintartalmú italok, mint energiafoko- zók túlzott fogyasztása egészségkárosító hatással bírhatnak, magas vérnyomás kialakulásához, szapora szívdobogáshoz, neurotikus túlérzékenységhez vezethetnek.

A fiatalok szívesen fogyasztják a koffeintartalmú italokat különböző céllal, napszaktól függetlenül. Szükséges lenne már gyermekkorban elkezdeni a fiatalok egészséges életmódra nevelését, hiszen az iskoláskorban helytelenül kialakult szokásokon a gyerekek későbbiek során már nem, vagy csak nagyon nehezen tudnak változtatni. A családban elsajátított helyes minták mellett - mivel a kutatásunk alapján a serdülőkorúak nincsenek tudatában az élvezeti cikkek egészségre káros hatásaival - az iskolai védőnők, tanárok szerepe kiemelt fontosságú. Az iskolának, mint szervezetnek mindennapokba ágyazott feladata a tanulók egészségének fejlesztése, ami a veszélyek ismertetése mellett az ún. „egészségerőkre” - az egészség protektív faktoraira - is kell, hogy fókuszáljon, így segítve elő az egészség választását előmozdító tetteket. ${ }^{11}$

\section{HIVATKOZÁSOK}

\footnotetext{
${ }^{1}$ Jasák H., Szente V. (2011). Mérlegen az energiaital. Élelmiszer, Táplálkozás és Marketing 8 (1-2), old. 61-65.

2 Központi Statisztikai Hivatal, KSH (2017). A rendelkezésre álló égetett szeszes italok, kávé, tea, dohány mennyisége. STADAT, [Online] 2017. június 1. [Hivatkozva: 2018. 10. 31.] https://www.ksh.hu/docs/hun/xstadat/xstadat hosszu/elm13.html

${ }^{3}$ Ahsan F., Bashir S. (2019). Coffee Consumption: Health Perspectives and Drawbacks.J Nutr Obes. Volume 2 | Issue 1

${ }^{4}$ Fekete K. (2011). A koffeinről. Egészségfejlesztés, 52(4), old. 32-35.

${ }^{5}$ Costa, B. M., Hayley, A., Miller, P. (2016). Adolescent energy drink consumption: An Australian perspective. Appetite, [Online] 2016. október 1. 105, 638-642. [Hivatkozva: 2018. 11. 12.] http://www.sciencedirect.com/science/article/pii/S0195666316302689

${ }^{6}$ Malinauskas, B. M., Aeby, V. G., Overton, R. F. et al. (2007). A survey of energy drink consumption patterns among college students. Nutr J. [Online] 2007. október 31. 6,35. [Hivatkozva: 2018. november 12.] https://nutritionj.biomedcentral.com/articles/10.1186/1475-2891-6-35

${ }^{7}$ Zsíros E., Balku E., Vitrai J. (2016). Egészségkommunikációs Felmérés Eredménye II.- iskolai felmérés. Egészségfejlesz és, [Online] 57(3), old. 21-40. [Hivatkozva: 2018. 11. 12.]

http://folyoirat.nefi.hu/index.php?journal=Egeszsegfejlesztes\&page=article\&op=view\&path\%5B\%5D=45

${ }^{8}$ Dojcsákné Kiss-Tóth É., Kiss-Tóth E. (2018). Energiaital fogyasztási szokások és egészségtudatosság a felsőfokú képzésben részt vevő hallgatók körében, Egészségfejlesztés, 59(4), old. 17-26. [Hivatkozva: 2019. 03. 20.] http://folyoirat.nefi.hu/index.php?journal=Egeszsegfejlesztes\&page=article\&op=view\&path\%5B\%5D=300 ${ }^{9}$ Emond, J. A., Sargent, J. D., and D. Gilbert-Diamond, D. (2015). Patterns of Energy Drink Advertising over U.S. Television Networks. In: J Nutr Educ Behav. 2015 Mar-Apr; 47(2): 120-126.e1.

10 Őri R., Karácsony I. (2019). Az alvás mennyiségi és minőségi változásai tizenéves korban - okok és háttértényezők. In: Balogh E., Jávorné Erdei R. (szerk.) TDK (kor)határok nélkül. Nyíregyháza, Debreceni Egyetem Egészségügyi Kar, old. 129-139.

${ }^{11}$ Karácsony I. (2018). Egészségről az iskolában - felvilágosítástól a fejlesztésig. In: Képzés És Gyakorlat. 16. évfolyam, 1. szám, old. 107-116.
} 